\title{
Suffering in silence: bodily politics in post-1995 French film
}

\begin{abstract}
Developing earlier research by the author that had sought to trace the specificity of the current wave of socio-politically engaged film, this article focuses in on the body, suggesting that it has become a core vector of 'raw' expressivity in recent French cinema due to the withdrawal of the discourse of the organised left as mediating instance. Brooks' celebrated analysis of melodrama and the political philosophy of Rancière and Laclau and Mouffe are drawn upon to examine the political work done by Cabrera's Retiens la nuit and Devers' La Voleuse de St Lubin. Engaging with the objectified, embodied and isolated social suffering that runs through current cinema, the two films' significance lies in their exploration of the possibilities of and obstacles to its articulation within an oppositional politics.
\end{abstract}

We focus here on made for television films by two women film-makers, Dominique Cabrera and Claire Devers, using them to raise some specific questions about the political articulation of embodied social suffering as well as more general ones about the current modes of appearance of the political within French film. Suggesting that the body is a key vector of the wave of socially engaged films that have been such a feature of recent French cinema, it first connects its central importance to the falling away of those discourses and institutions that used to mediate the social before examining how the two films considered seek to give a political sense back to embodied experience. The article comes out of a larger study that seeks to identify the originality of the current wave of engaged films. ${ }^{1}$ More specifically, it seeks to build from thoughts originally set out in a paper published in Modern and Contemporary France (O’Shaughnessy, 2003), and which I will summarise here as a way of providing a more general frame for what is to follow. In that earlier work, I suggested that despite some variations in terminology a range of critics converge in identifying the emergence of a new realism (a neo neorealism?) associated with the mise en scène of a fragmented, disruptive and undigested real and linked stylistically with less polished cinematography, relatively low budget film-making and non-star or amateur actors. ${ }^{2}$ A key part of the explanation I developed for the characteristic rawness of this realism was the decline of the institutional left and the deliberate and systematic dismantling of the organised working class.

During much of the twentieth century, as we know, left wing organisation and working class identities worked to provide universalising mediations for local and particular struggles and oppressions, connecting each specific instance to the broader spatio-temporal frame of a narrative of national and international emancipation. Struggles and oppressions with roots in economic inequalities are still all too present. Yet they are no longer taken in hand in the same way by the 
organised left and because of this their mode of appearance has shifted. They have acquired a new raw immediacy by being disconnected from a tradition, deprived of the promise of a better future, and detached from struggles elsewhere. Crucially, too, they have lost their voice, the voice that was the institutionally grounded discourse of the left. It is the falling silent of this mediating voice, and the resultant focus on the raw violences of the real that lies, I have suggested, at the heart of the originality of the current wave of socially and politically engaged films, and, moving from summary of my earlier piece to the matter of this current article, it is also this falling silent and rawness that explains why the corporeal has taken on such a pivotal role.

Within this broader context, the body's new cinematic centrality can be understood in two related ways. Firstly, it should be seen as a symptom of the massive social regression that has taken place in European societies over the last twenty to thirty years. With the decline of collective solidarities, the new brutality of the globalising economy and the increasing inability or unwillingness of the State to act as a cushioning force, systemic violences increasingly impact directly on individuals or small groups, and this impact, revolving as it does around issues of shelter, nourishment, mobility and group reproduction, inevitably transmits itself to and through the body. I would not of course suggest in some reductive way that this embodied suffering is somehow simply reflected in film. What I am suggesting is that the transformations in the social terrain and in their political prise en charge have been so dramatic that film cannot but respond to them. Secondly, the focus on the body as a site of immediate suffering and purely local resistance is a symptom of the withdrawal of the discourse of the left as mediating, universalising instance. The body's muteness is made to figure this falling silent and disabling entrapment in the individual and the here and now, while at the same time, paradoxically, it becomes a core vector of the expressivity which is needed to mediate that which has been made raw. And it is perhaps in this speaking of a silence, this expression of the crying need for, yet lack of, a properly political mediation that its political use-value lies.

This line of argument about the mute yet eloquent body owes a great deal to Peter Brooks' classic work on nineteenth century melodrama (Brooks, 1976). Brooks' core thesis is that the heightened expression of melodrama is a way to restore moral transparency to a postsacred, post-revolutionary world. He suggests that the body is made to figure the loss of moral legibility through its silence while compensating for the same loss through its ability to externalise and make visible the inner life and worth of characters. Brooks' work is perhaps useful in seeing how the raw and often melodramatic corporeality of current French film might be intrinsically connected to the falling silent of the left. ${ }^{3}$ It is surely significant that a considerable number of recent French films juxtapose reference to the left's demobilisation with a focus on the 
bodily and the raw, while others explore alternative universalising discourses such as republicanism, the law, or humanitarianism that could perhaps take social struggle and embodied suffering in hand and give it meaning. By so doing, one might suggest, these films are active participants in a broader and dispersed working through of the consequences of the historical defeat of the twentieth century left.

The line of argument I will develop also owes much to the thought of Chantal Mouffe and Ernesto Laclau, both in its original expression in Hegemony and Socialist Strategy (Laclau and Mouffe, 2001) and in its more recent development by Laclau, in dialogue with Judith Butler and Slavoj Zizek, in Contingency, Hegemony, Universality (Butler, Laclau and Zizek, 2000). Laclau and Mouffe's theoretical starting point is the work of Gramsci and his recognition that political struggles are not spontaneously generated by social antagonisms but depend upon their contingent articulation within civil society in the context of a broader struggle for hegemony. They stress that a specific grievance, over wages, for example, has to be articulated with a more general wrong, done to a class for example, before it becomes a truly political struggle. In the process, of course, both the specific grievance and the universalising instance of the general wrong are transformed, the former by its articulation within a politics, the latter by its connection to a specific content which simultaneously grounds and contaminates its universality. Political articulation, they stress depends on the establishment of equivalences between different causes so that each is raised from particularity and made available to the universalising claims of a broad counter-hegemonic movement. It also depends, crucially, on the prior positing of a fundamental social antagonism, the identification of a common enemy being a necessary moment in the establishment of the chain of equivalences that can pull together a set of diverse struggles. At the present moment, Laclau notes in his dialogue with Zizek and Butler, and following the shattering of its traditional imaginaries, the left urgently needs to develop an overarching oppositional discourse to enable the translation of individual to general claims and to mount a counterhegemonic challenge to ascendant neo-liberalism (Butler, Laclau and Mouffe, 2000: 211).

I would suggest, broadly, that Mouffe and Laclau can help us to think through the current fragmented mode of appearance of the social in a French cinema that focuses on 'raw', local struggles that often seem to cry out for a broader discourse of opposition that would take them in hand and give them meaning through connection to other struggles. More specifically, I will use their work to explore the second of the two films that I will consider, Retiens la nuit, a film which by the confrontational bringing together of the striking railway workers of 1995 and a single mother on the breadline seeks to carry out exactly the kind of equivalential articulation of social struggles that Mouffe and Laclau describe. 
The third source I will turn to is Jacques Rancière, particularly his mid-1990s work La Mésentente (Rancière, 1995). Rancière draws a sharp line between what he calls the police order and the political. The former encapsulates all that contributes to the maintenance of the established system of identifications and relationships and regulates participation in the logos, the language that names and orders socio-economic places, shares or functions. The latter begins with dissensus, with the naming of the wrong done to an exploited group by the denial of their fair part of the general social product and, more specifically, of access to the logos. Language is central to Rancière's analysis. Politics begins when, refusing the relegation of their self-expression to mere animal noise expressing bodily pain or pleasure, the oppressed claim their right to a public voice, and to a say, not in a negotiation between private interests, but in the sharing of the commons. If equality is the single principle upon which all authentic politics are based, the primary equality is before the word, and the initial conflict is always over the very existence of a shared stage. Based in no pre-existing, substantive identity that would inevitably be a reflection of the status quo, political subjectification instead depends on dissent and dis-identification. The people, the proletariat or women are not groups that argue from their pre-allocated silencing and subordination but come into existence through the naming of the wrong done to them and through the polemical renaming of the social order.

I would suggest that Rancière’s thought is generally useful for thinking about a cinema which so often seems to figure the tension between the embodied sufferings and struggles (the animal noises) of isolated groups and individuals and the falling silent of a discourse of the left that once connected them to the logos. I will turn to him more specifically in my discussion of Devers' La Voleuse de St Lubin, a film about one woman's fierce struggle against her allotted social role of assistée and her desperate attempts not simply to resist her situation but to take part in public speech and to refuse the political silence and social objectification imposed upon her. Laclau and Mouffe's assertion of the necessarily contingent articulation of social struggles will also be evoked to explain the different ways in which the woman's fight is translated during the course of the film.

Both films were part of Arte's well received series Droite / gauche, broadcast in 2000, which was intended both as general support for an explicitly political cinema that was felt to be currently lacking and as a more specific interrogation of the present validity of what used to be the defining political faultline between left and right. The commissioning editor of the series, Arte's Pierre Chevalier said that it was the cinéaste's central role in defence of the sans-papiers in 1997 that made him turn to them for commentary on the political situation (see Humblot, 2000). What interests me specifically about the two films chosen is how they explore the key 
issue of the reconnection of individualised, corporeal struggles to the universal, a reconnection which seems a precondition for their effective re-politicisation. ${ }^{4}$ Crucially also, and unlike others in the series, they seek to restore currency to an antagonistic construction of the social that would allow for the building of a counter-hegemonic project along the lines described by Mouffe and Laclau and endorsed by Rancière. ${ }^{5}$

The first of the two films I will look at is by Claire Devers and is entitled La Voleuse de St. Lubin. A sobre and beautifully acted drama, it is based on a real fait divers that occurred in Poitiers in 1997. The film tracks the struggles of a single mother, Mme Barnier, who has two daughters to feed and house, and an ageing car on which she depends to get to her work in a meat processing factory. Determinedly self-reliant, she refuses to go into debt despite her pressing needs. The drama is set in motion when, following her failure to gain increased support from a state and the breakdown of her car, she cracks and steals large amounts of meat from three separate supermarkets. The meat is to make a change from her children's staple diet of pasta which provides them with energy but not with the protein to make their bodies grow and which thus puts their future and the reproduction of their social group at risk. Mme Barnier is charged, tried and acquitted by a left-leaning woman judge who deems that she was en état de nécessité. Picked up by the media, her case becomes a national cause célèbre with opinion polls suggesting a public evenly split and with her local National Front seeking to instrumentalise her case. The state appeals against the initial verdict and she is declared guilty by a male-run and more rightward leaning tribunal.

Before considering the film's multiple articulations of its raw materials (my main concern here), I would like to dwell briefly on the collision it engineers between the worlds of consumption and production. Mme Barnier, we noted, works in a meat-processing factory while her crime takes place in a shopping centre. Her work involves removing the waste materials from the meat preparation process and washing away the blood and other soiling that result from the butchery. As she works, other women are repeatedly seen wrapping up the sanitised final product that will appear on the supermarket shelves. Mme Barnier is thus part of a broader process of invisibilisation by which production, its messy violences and its constraints, hide themselves to allow for consumption's utopian self-presentation. By staging the encounter between two worlds normally held separate, and like a number of other films Devers carries out perhaps banal but nonetheless necessary political work. ${ }^{6}$ Showing the separation between a food worker and the food she cannot afford, she restores one of the basic planks of a politics built around exploitation. More subtly, she perhaps also provides reflexive commentary on the wave of broadly social realist films to which her own piece belongs, suggesting how they deliberately and necessarily 
draw our attention back to messy social processes rather than allowing 'innocent' consumption of attractive consumer products. The raw meat in the factory has obvious affinities with the rawness of social misery deprived of adequate political mediation and whose invisibility a socially engaged cinema can resist by close attention to individual suffering. Like a number of other films, La Voleuse de St. Lubin maintains a close if not obsessive focus on the body and face of its chief protagonist, tracking her frustrations, her pain, her silences and her outbursts while recording her isolation. ${ }^{7}$ By so doing, and along the lines described by Peter Brooks, it gives a melodramatic eloquence to her 'raw' pain.

Returning now to our main thread, let us consider, in their narrative order, the different articulations of Mme Barnier's social misery. The film opens with an encounter with social services. A state employee opposes Mme Barnier’s forceful claiming of her due (almost her first words are 'j'ai droit à ...') with rigid bureaucratic and numerical criteria that define her as a nondeserving case. It is suggested that she might try one of the private charitable organisations that provide support to the poor. She is also told that if she owed money, she could be helped. Voicing a working class respectability that has effectively become a dead language, she asserts her selfreliant refusal of debt. What is at stake here is not simply financial. On one side of the glass that underlines the separation of the two parties, the state agent tells Mme Barnier that she has become a category, a social object deserving or not deserving support from a henceforward assistencial state. On the other, is someone who asserts her frustrated right to be a speaking subject and, in Rancière's terms, to participate in the logos. Significantly, this initial failure to make herself heard is immediately followed by a sequence concerning the European elections. In conversation with three other mothers, Mme Barnier suggests that she has voted for the Communist party not because she believes that they will take her problems in hand, but as a way of signalling to the politicians, through a protest vote, that they are not hearing her. This attempt to maintain some vestige of a public voice only underlines the gap that now exists between social suffering and the political forces that used to take it in hand.

The trial that follows her theft seems to provide Mme Barnier with a public stage upon which to voice her refusal of her desperate social situation. By ingeniously quoting the figures for the calorific needs of a child from Prima, a woman's magazine, and through painstaking detailing of her accounts, she translates the bodily needs behind her theft into the monetary figures that the bureaucratic machinery of the court can deal with and improbably bridges the gap between her embodied struggle and the disembodied idioms of power. The judge rules in her favour, citing the état de nécessité, a statute enacted at the end of the nineteenth century to deal with the specific case of a woman who had stolen bread. ${ }^{8}$ The verdict is reported upon favourably by Le Monde, 
and thus through the institutional mediation of the courts and the press and the juridical mediation of republican law and a discourse of rights, a local and embodied tort seems to been raised to the level of a public political wrong that calls the workings of the system into question and restores the broken link between the political and the social.

A brief sequence in the judge's car allows us to hear how the case is taken up by national radio. It is the second item on the news sandwiched between a report of the President's stagemanaged visit to a school and another concerning the day's level of the CAC40, the French equivalent to the British index of 100 leading shares. The social thus comes to public notice in the form of a sensational fait divers, juxtaposed to, but not connected with a politics reduced to public relations and an economic sphere where share price levels have come to be the measure of success or failure. However, this pacifying separation of domains is threatened when it is suggested that the Barnier verdict might encourage a more general 'incivisme alimentaire' and thus, by implication, cause the forceful intrusion of embodied social misery into the sanitised domains of the economic and the political. Coming under pressure, the judge now insists that the case is too individual to set any precedent and thus throws it back again upon its particularity.

The case is then adopted by the Front National, who use the particular wrongs it raises poverty, access to decently paid work and affordable accommodation - to root its odious discourse in the concrete and the everyday while shifting the focus from a racially neutral bodily wrong (the inability of a mother to nourish her children) to a racialised issue of skin colour. This intervention underscores the Front's crucial ability to bridge the embodied particular to its own racialised version of the universal while underscoring how other forces which could have articulated the case more constructively have abandoned the terrain. Taking things literally into her own hands, a furious Mme Barnier frantically prises the Front's leaflets out of her neighbours' letter-boxes and makes an angry visit to their offices to refuse their wrongful rendition of her case. If her earlier protest vote seemed to say, 'you are not hearing me', her message now seems to be 'this is not what I am saying'. Although they have no positive semantic content, these interventions signal her silencing and thus contest the existing allocation of the right to public speech.

An appearance on national television gives her one last forum. Covering her face to resist media exposure, she polemically re-narrates her case, suggesting that she had not simply cracked (a private, emotional response to social suffering) but had sought to protest against politicians' inaction in the face of a social misery that they had anticipated and should have acted to prevent. This re-narration underlines the lack of a fixed meaning attached to social suffering (along the lines described by Mouffe and Laclau) and its availability and desperate need for public voicing 
and political articulation. Although understandable in conventional narrative terms, Mme Barnier's head covering during the interview again suggests the film's reflexive engagement with cinema's treatment of the social. It underscores the character's presence as a subject with a public voice who refuses objectifying representation of her face. The film would seem to be suggesting that if cinema is to take it upon itself to bring social misery to public visibility, it needs to beware of the voyeurism and sensationalism that its own means push it towards.

The Barnier case is the object of an opinion poll whose self-cancelling yet apparently exhaustive results (49\% who consider the theft justified against $48 \%$ who condemn it) indicate the real nature of this form of consultation which brings to visibility a people always already pacified by atomisation and purely mathematical re-amalgamation. Despite her own atomisation, Mme Barnier nonetheless clings disruptively to her capacity for a political subjectivity based on the expression of a wrong, thus ruffling the smooth surface of a consensuality in which everyone's opinion seems to count. ${ }^{9}$

The film moves to a conclusion as the judiciary regroups and the state appeals the initial verdict. Again relying on a bureaucratic language of accountancy and legal codes, the retrial retranslates Mme Barnier's case, condemning her act as a merely criminal one, thus simultaneously reparticularising and depoliticising it. The left leaning judge who had originally amplified and legitimised her voice is herself condemned to silence when the case is taken out of her hands. She asks for a disciplinary hearing so that, like Mme Barnier, she can use a public stage to resist the renaming of a wrong as an individual and thus private failing. Her request is denied. The earlier, heroic translation of embodied social misery into the idiom of power has now been successfully erased. It remains for Mme Barnier to don her mother's black widow's veil for the television cameras. Having ultimately failed to translate a particular and embodied struggle into a general, political wrong, all she can do is to assume her defeat and make her body a mediating symbol of her failure, testifying to her silencing, while again refusing the voyeuristic exploitation of her image.

La Voleuse de St. Lubin works on some similar terrain to a range of other recent French or Franco-Belgian films that track the embodied social suffering of characters condemned to struggle as individuals by the shattering of the working class into fragments and the undoing of mediating instances. ${ }^{10}$ Its virtue is to straddle the faultline that Rancière describes between participation in the logos and banishment to the subhuman realm of suffering and pleasure without a political voice. Its position across this faultine helps explain the complexity and effectiveness of the work that it does. On the one hand, it refuses the invisibility of a social suffering made raw by the deprivation of political mediation while engaging with the processes 
that produce that same invisibility. On the other, by its attention to the protagonist's attempts to give public expression to the wrong done to her, and to her steadfast refusal of instrumentalisation or voyeuristic objectification, it reminds us of the need for a properly political prise en charge of the social that does not simply take suffering in hand but which gives a voice to the oppressed.

Our second film, Dominique Cabrera's Retiens la nuit, known in its longer cinematic version as Nadia et les hippopotames, works on some similar terrain. It again centres on the divide between a public, political language and the embodied affectivity of the private domain. But whereas our first film associates entrapment in the melodramatic body with exclusion from the language of power, this film uses embodied affectivity as a common ground upon which to effect translations between different modes of appearance of social struggle as a pre-condition for rebuilding the shattered dramaturgy of the left and for breathing new life into a political vocabulary threatened with fossilisation by empty repetition and divorce from embodied experience.

The film's core character is Nadia, a single mother, who struggles over accommodation while moving from one short-term employment to another. The film stages her encounter with the railway-workers who were on strike in December 1995 and thus engineers a collision between what remains of an organised Fordist working class (the weighty and thus hard to move hippopotames of the title), and a depoliticised lumpen-proletarian. Although the encounter is highly contrived, it does work to bring together two radically different modes of appearance of the social and to find a common ground between them that will allow two particular claims to come together by naming a general wrong. One form of the social, represented by the railway workers, is characterised by collective action and is politically mediated by the institutions and discourses of the left. It has both a past and a future that, as the struggle centres on pension rights, it is struggling to defend. Like Mme Barnier in La Voleuse de St Lubin, Nadia, the lumpenproletarian, is part of a social terrain of individual vulnerability and immediate need that lacks any political or institutional mediation. She is, one might say, a foreign body in the railway workers' internal debates, bringing with her a baggage that they can at best greet with bemused tolerance. She is seeking out the railwayman father of her child in order to give the infant away to him so that he can ensure its well-being and give it a future in a way that she never can. By an astonishing coincidence, one of the strikers that Nadia meets is the errant train driver's wife. The emotional disruption of this melodramatic encounter and the strike's suspension of conventionality prepare the ground for the film's utopian reworking of the relationship between the corporeal, the affective and the political. 
As the film begins, and as one might expect, Nadia is an ironic, sometimes hostile witness to internal debates that do not engage with her concerns. Compared to her, the workers are privileged, as is underlined by a perhaps predictable sequence in a supermarket when they can make gifts and discerning consumer choices while Nadia (like Mme Barnier) steals to feed her child and has to do without things that are necessary. And because they are privileged, and their struggle does not seem to include hers, their tous ensemble, the slogan of the 1995 strikes, seems condemned to be a purely sectoral, conservative and indeed corporatist claim.

Narrow self-interest was indeed the accusation levelled at the strikers in 1995 by the right and a good number of intellectuals, notably those who signed the Esprit petition who seemed happy to endorse the Juppé government's self-presentation as the representative of the general interest and of the long term good. ${ }^{11}$ But tous ensemble, initially a call to the private sector to join with public service workers in a united front, broadened in unexpected directions as groups representing the excluded mobilised and entered into sometimes uneasy dialogue with the strikers. This interaction helped the strike transcend its apparently corporatist beginnings and to disarm the politically disabling playing off of workers defending their acquis against the excluded, the former somehow being deemed responsible for the situation of the latter. It thus helped in the establishment of a more general case for the defence of an ethic of public service and a refusal of neo-liberalism's seemingly unopposable drive to dismantle the inherited gains of the post-war welfare era. Lacking a longer term political project, but having mutated to encapsulate a general defence of foundational left-wing values of equality and solidarity tous ensemble thus seemed able to propose at least some basis for a counter-hegemonic politics. The film's staged collision between the 'excluded' Nadia and the railway workers might seem simply to be restaging this core encounter of 1995, while its articulation of different voices might seem only to be following the 1995 movement's own self-rearticulation and broadening. ${ }^{12}$ Such a view does not however do justice to the specific processes through which the film finds a ground for translation between Nadia and the strikers in order to turn its own version of tous ensemble into a general imperative.

It is, we remember, December. Nadia has a small child. The child needs to be kept clean and warm, fed and sheltered, especially once snow begins to fall. Nadia herself, a distinctly bodily encumbrance, is burned by a heater and needs first aid and later vomits and needs to have her face cleaned. These responsibilities are initially marginal to the strikers' core concerns although they assume them willingly enough. However, when a van taking two of them and Nadia round the périphérique runs out of fuel, the need to keep themselves and the child warm becomes a basic one that can only be met first by running and then by huddling together. 
Translated into the fundamentals of bodily survival and of joint responsibility towards the vulnerable infant, tous ensemble, so to speak, takes on flesh, and transcending its sectoral origins, becomes an expression of a shared human need for warmth and togetherness. Under such conditions, Nadia can utter in successive breaths two phrases from apparently incompatible 'phrase regimes,' connecting the ' $\mathrm{j}$ 'ai froid' of bodily sensation meaningfully to the 'tous ensemble' of political ideology, thus joining together the experiences of the lumpenproletarian and of the rump of the organised working class.

In another not dissimilar sequence, and in perhaps equally contrived fashion, the film also brings together a non-striking male driver and a striking woman ticket collector by having the latter improbably ask the former for a lift despite the fact that she has been part of the group that has literally smoked him out of his workplace. Brought into enforced intimacy by the heightened circumstances and the confined space of the car, the two discuss both the personal and the political in a way that transgresses traditional boundaries between the two domains and opens space for the discovery of some commonality between the two opponents. Conventional political discourse locks both into opposed and familiar attitudes with the non-striker voicing familiar objections to the action of an allegedly privileged set of workers. The personal, however, allows real dialogue to emerge. Both unsurprisingly express anguish at their incapacity to ensure the futures of their families. The striking woman then remarks that, although they are subject to the same uncertainty, she faces it with others, while he is condemned to face it alone. Translated into the language of the personal, the political reconnects to experience and the difference between solidarity and isolated individualism again becomes meaningful. More broadly, the film's tracking of bodies against predominantly external, nocturnal decors illuminated by the strikers' braziers provides a suitably elemental terrain for translation between embodied experience and political discourse to take place. A series of physical contrasts between warm and cold, bright and dark, sheltered and exposed, groups and isolated individuals allows the strike's tous ensemble to take on flesh and root itself in the world. ${ }^{13}$

As the film ends, Nadia is first drawn into the warm sociability of a group of strikers in a café before listening attentively to the speech by one of the two union delegates with whom she has spent the night. Whereas she was a disengaged and impatient figure, she is now an attentive listener to a discourse which effectively interpellates her. Capitalising on the political work that has taken place in the film, the delegate can propose a redrawing of the socio-political terrain that pulls together the different fragments of what was the working class and reconnects with rejected elements of its heritage while re-embedding the language of politics in (his own) lived experience. The speech evokes his Stalinist father, his experience of a series of short-term jobs 
and his return to 'la boîte' (the SNCF) to provide security for his children. It continues by suggesting that they are all held by fear of the future, and that the unemployed and migrant labour are used to cow the working class. It goes on to stress the importance of unity between strikers, non-strikers and the unemployed. It ends by saying ‘il faut que la peur change de camp’ (a familiar slogan from 1995), eliciting the comment, 'et ils ont eu peur'.

The film lends itself perfectly to analysis in terms of Laclau and Mouffe's account of the preconditions for a struggle for hegemony. It begins with a social landscape marked by the politically disabling split between inclusion and exclusion but reorders the social terrain by reinscribing the core antagonism between capital and labour at its heart, thus allowing for the identification of a common cause between different fractions of the dominated. ${ }^{14}$ Although not without its problems, Cabrera's film is significant for being one of the first attempts to reconnect the individual social suffering that traverses the French cinema of this period to a polemical, political voice. Its interest lies less at the explicit, discursive level, where it can at best offer a highly simplified version of some of the debates of 1995, than in its mobilisation of the specific resources of cinema to create a terrain upon which to reassemble the cast and restore the grounds of the left's shattered imaginary. ${ }^{15}$

\section{Conclusion}

Both of the films chosen underline cinema's power to track and make eloquent a social suffering condemned to muteness by the historical defeat of the left and the resultant silencing of adequate political mediation. But neither stops there. Building from the ground up (the atomised social pain of La Voleuse de St Lubin, the elemental terrain and shared fear and vulnerability of Retiens la nuit), and exploiting cinema's ability to hold the corporeal and the discursive in productive tension, they underline both the need for and barriers to a properly political prise en main of the current wave of embodied social suffering. They also tentatively begin to reinscribe the kind of antagonistic construction of the social without which this necessary politicisation cannot occur. In so doing they are contributing in their way to a broader and urgent process of thinking through and rebuilding.

\section{References}

Beugnet, Martine (2000)., 'Le souci de l'autre: réalisme poétique et critique social dans le cinema français contemporain’, in Iris, 29, Spring 2000, 53-67.

Brooks, Peter (1976), The Melodramatic Imagination, New Haven: Yale. Butler, Judith, Laclau, Ernesto and Zizek, Slavoj (2000) Contingency, Hegemony, Universality: Contemporary Dialogues on the Left, London: Verso. Cabrera, Dominique (2000a) 'Décembre 95,' Cahiers du cinéma, 544, March 2000, 32. 
Cabrera, Dominique (2000b), interviewed by Audé, F. and Tobin, Y. in Positif, 470, April 2000, 35-39

Duval, J et al, (1998) Le 'Décembre' des intellectuals français, Raisons d’Agir, 1998.

Humblot, Catherine, 'Six films, un thème: gauche-droite', Le Monde, 28/2/2000, 4.

Laclau, Ernesto, and Mouffe, Chantal (2001), Hegemony and Socialist Strategy: Towards a

Radical Democratic Politics (Second edition), London: Verso

Lévy, Albert (2002), 'Punir les coupables, secourir les malheureux' in L'Humanité, 1/8/2002,

consulted at www.humanité.presse.fr/journal/2002-01-08/2002-01-08-26794, on 7/5/04.

O’Shaughnessy, Martin (2003) 'Post-1995 French cinema: return of the social, return of the political?’, Modern and Contemporary France, 11:2, 189-203.

O’Shaughnessy, Martin (forthcoming), 'Reprise, la mort de la banlieue ouvrière et la naissance de nouvelles formes d'engagement politique.' in Hayes, Graeme and O’Shaughnessy, Martin (eds), Cinéma et engagement, Paris: L’Harmattan

Rancière, Jacques (1995), La Mésentente: Politique et Philosophie, Paris: Galilée.

Rancière, Jacques (1999), 'La politique n'est-elle que de la police?' in L'Humanité, 1/6/99, consulted at http://www.humanite.presse.fr/journal/1999-06-01/1999-06-01-290580 on 7/5/04)

Rancière, Jacques (2001), 'L’exclusion existe-t-elle?’, www.endp.fr/tr_exclusion/rep_ranc.html, consulted 21/1/03).

\section{Notes}

${ }^{1}$. The larger study has been made possible thanks to an AHRB matching sabbatical. My warm thanks are therefore due to the AHRB and to Phil Powrie and Elizabeth Ezra for their support for the project and also to Sue Harris for her support for this piece.

${ }^{2}$. For an account of stylistic features associated with the films under consideration, see Beugnet (2000).

3 . For a more developed application of Brooks' analysis of melodrama to contemporary French social cinema see O'Shaughnessy (forthcoming).

${ }^{4}$. Although it is not the subject of this piece, it is surely not an accident that both of these films were directed by women. Both show specific sensitivity to the vulnerability and lack of a political voice of single mothers and of women on short-term or part-time contracts. Both too would seem to build productively on the inherited experience of a feminist politicisation of the personal and the corporeal.

5 . Rancière usefully summarises core parts of his conception of the political in an interview given to L'Humanité in 1999. He says, 'S'il existe une somme de microsituations sociales déterminant des formes de sensibilités politiques, des formes de résistance à ce qu'on pourrait appeler l'ordre "policier" ou purement gestionnaire, il n'y a pas de politique tant qu'il n’y a pas de capacité d'universalisation de ce qui est en cause dans telle ou telle situation, que ce soit le mouvement de 1995 ou celui des sans-papiers. Il ne s'agit pas seulement de fédérer des forces, mais de constituer des sujets politiques qui aient vocation à universaliser le conflit. La politique, c'est le conflit, pour autant que celui-ci prenne une fonction universelle ...' (Rancière, 1999). Despite its lack of any explicit reference to Laclau and Mouffe's work, this comes close to summarising their account of the conditions of emergence of a counter-hegemonic movement.

${ }^{6}$. Guédiguian's Marius et Jeannette (1997) shows its heroine working at a check out taking money for paint that she herself needs to steal from a disused factory. Mehdi Charef's Marie-Line (2000) focuses on a group of cleaning women who work in a shopping centre at night, thus reinscribing hard labour within the 'free' spaces of consumption. Zonca's La Vie rêvée des anges (1998) moves its two heroines between sweat shop labour and shopping centre, while Vernoux's Rien à faire (1999) repeatedly brings an unemployed man and woman from radically different social groups into the same supermarket. In each case, the films work to engineer collisions between the utopia of consumption and the constraints associated with production and poverty.

${ }^{7}$. It is worth noting that Mme Barnier is told that her crime is to have stolen with her hands rather than with a cheque that would not be honoured. The film's world would seem to be one where the intrusion of the raw is not to be tolerated. 
${ }^{8}$. The state of necessity was first mobilised in 1898 by Judge Magnaud in the case of Louise Ménard (see Lévy, 2002) Its evocation, a century later, highlights the deliberate undoing of the social gains of the Twentieth century. It is perhaps also a reminder that, although an inevitably conservative institution, the law can be seen as an embedded form of the outcomes of earlier struggles and thus a valuable resource in times of political retreat. Recent times have seen it used by José Bové for his defence in the Millau case, by the homeless and by campaigners against third world debt. This judicial turn is no doubt closely related to the closing of more traditional political avenues and to the rise of new social movement who use the law as a regular part of their struggles.

9 . In Laurent Cantet's Ressources humaines there is also a poll which lends itself to a similar analysis. It is part of the post-class, consensual regime of the first part of the film whereby the workers' opinions are counted but clearly do not count in the running of the enterprise. It is only in the face of un-negotiated redundancies, and as a result of the polarisation of a strike, that they rediscover a meaningful voice, one that polemically states their claim to a say in decisions that affect them and organises them into a group that opposes another group. That film provides a perfect illustration of the difference Rancière traces between the entirely visible people of depoliticised consensuality and the people of an authentic politics. The latter can only appear through the subjectification of a wrong (Rancière, 1995: 143-146).

${ }^{10}$. I write Franco-Belgian rather than simply French with the specific and key instance of the Dardenne brothers closely in mind.

${ }^{11}$. For a polemical account of reactions to the 1995 movement see Duval et al (1998)

12. The film does in fact draw to a degree on the voices of 1995. Accounts of its gestation indicate that director Cabrera and co-writer and sociologist Corcuff were able to call upon other sociologists' interviews with strikers and recordings of their Assemblées Générales. The two scriptwriters were also familiar with the films shot by the strikers themselves during their action and which formed the basis of discussions that brought together workers and intellectuals at the Cinémathèque français in 1997. Finally, the railway workers that formed part of the cast were allowed to improvise during the shooting and thus inflect the direction of the film (Cabrera, 2000a: 32.)

${ }^{13}$. Cabrera notes, for example, how much work went into the lighting to give a sense of warmth and optimism to what was seen despite the night-time shooting. One might also comment on the cheerful primary colours of the jackets of the two female leads (Cabrera, 2000b).

${ }^{14}$. Rancière (2001) suggests that exclusion is part of a broader consensualism which, evacuating the grounds for a conflictual articulation of the social, assumes that everyone is a priori included and that exclusion is therefore a pathology to be treated. Whereas older forms of domination could be contested because they named themselves openly - by telling the workers, for example, that they had no right to a say in the division of the commons - exclusion resists symbolisation as an object of struggle.

${ }^{15}$. One obvious problem is a plot that stretches belief. Another is an all embracing inclusiveness that suggests a film torn between a necessary rethinking of the conditions for rebuilding political unity and an understandable desire to evade the irremediable fragmentation of the old working class. Rancière, for his part, used it as a key example when he argued that the mechanisms designed to ground the realism of social realist fictions had finally ground to a halt (for an account of his analysis see O’Shaughnessy (2003)). 